\title{
BRINGING THE WELLS BACK INTO OPERATION BY FORMATION HYDRAULIC FRACTURING
}

\author{
•. устышев \\ D. Kustyshev \\ «юмен гипрог з», г. юмень
}

лючевые слов : р сконсерв ция; скв жин; гидр влический р зрыв пл ст

Key words: bringing back into operation; well; formation hydraulic fracturing

есторождения природного г 3 п дной ибири относятся к числу н иболее крупных месторождений по з п с м г 3 в оссии и во всем мире.

дним из перспективных н пр влений поддерж ния проектных объемов добычи углеводородного сырья является к пит льный ремонт скв жин и, в ч стности, р сконсерв ция p зведочных скв жин или р нее 3 консервиров нных эксплу т ционных скв жин.

сновной проблемой р сконсерв ции скв жин является плохое техническое состояние скв жин и н личие большой зоны кольм т ции, что объясняется длительным периодом н хождения скв жин в бездействии, достиг ющим порою более 20 лет [1].

дним из способов решения этой проблемы может ст ть метод гидр влического р зрыв пл ст ( ), примененный при восст новлении г зодин мической связи пл ст со скв жиной.

месторождениях п дной ибири метод 3 рекомендов л себя к к один из н иболее эффективных методов интенсифик ции приток в нефтяных, г зовых и г зоконденс тных скв жин х. егодня его р звитие происходит по н пр влениям совершенствов ния технологий, применяемых жидкостей и используемой техники, т кже методов проектиров ния и контроля п р метров [2-4].

мировой пр ктике н считыв ется множество технологий . ибольшее р спростр нение 3 рубежом получил технология последов тельного 3 к чив ния в трещину р 3рыв пропп нт , р злич ющегося между собой к к по фр кционному сост ву, т к и по другим свойств м. к пр вило, перед проведением в обр б тыв емом интерв ле проводится повторн я перфор ция перфор тор ми с высокой пробивной способностью, или выполняется мини- с целью уточнения технологии основного . идкость $\mathrm{p}$ зрыв 3 к чив ется с постоянным р сходом до достижения д вления р зрыв . ерез 20-30 мин 3 к чив ние прекр щ ется, з бойное д вление сниж ется, трещин смык ется. ценив ется утечк жидкости р зрыв в пл ст, и по поведению д вления определяются прониц емость и приемистость пл ст $[5,6,7]$.

ля условий п дной ибири, в ч стности при р сконсерв ции скв жин ов ненковского месторождения, можно рекомендов ть двухфр кционный уть технологии 3 ключ ется в 3 к чив нии основного объем среднепрочного пропп нт тип 20/40 меш $(0,850-0,425$ мм) с последующим 3 к чив нием средне- или высокопрочного пропп нт тип 16/20 меш $(1,180$ 0,850 мм) или 12/20 меш (1,700-0,850 мм) в количестве от 10 до $40 \%$ от общего объем .

к честве р склинив ющего трещину м тери л - пропп нт - можно рекомендов ть прочный ок т нный кв рцевый песок, который должен отвеч ть следующим требов ниям:

- обл д ть дост точной прочностью, чтобы не быть р зд вленным м ссой вышележ щей толщи горных пород и не быть вд вленным в поверхность трещины р зрыв ;

- $\quad$ иметь форму, приближенную к ш ру (округлость и сферичность зерен).

ля 3 крепления трещины р зрыв шириной от 0,50 до 2,00 мм можно предложить следующие $\mathrm{p}$ змеры фр кций р склинив ющего м тери л :

- в уд ленной от з боя ч сти скв жины н р сстоянии от 0,33 до 0,42 мм - в р змере $15 \%$ от объем р склинив ющего м тери л ; или при ширине трещины от 0,33 до 0,42 мм;

- в средней от з боя ч сти скв жины н р сстоянии от 0,69 до 0,83 мм - в р змере $70 \%$ от объем р склинив ющего м тери л ;

- в ближней от з боя ч сти скв жины н р сстоянии от 1,40 до 1,70 мм — в р змере $15 \%$ от объем р склинив ющего м тери л .

ля повышения эффективности р склинив ния трещины в последнюю порцию пропП нт следует включ ть специ льную доб вку. к честве доб вки можно использов ть специ льное гибкое стекловолокно определенной толщины и длины (н пример, по технологии «PropNet»), препятствующее нез пл ниров нному выносу пропп нт из трещины н з бой и д лее в г зосборный коллектор. 
тери л доб вки должен иметь плотность, близкую к плотности пропп нт . онкретный выбор стекловолокон основыв ется н их устойчивости к воздействию флюидов в пл стовых условиях. ороткие, м лого ди метр волокн менее эффективны в упрочнении пропп нтной н бивки. текловолокно ди метром от 10 до 20 мк и длиной 0,01 м обеспечив ет м ксим льную устойчивость н бивки и несложно в обр щении. ри этом к ждое волокно должно конт ктиров ть к к минимум с пятью ч стиц ми пропп нт . олокн следует доб влять только в 3 верш ющую (от 15 до $20 \%$ ) ч сть 3 к чив емого пропп нт . одерж ние стекловолокн не должно превыш ть 1,5\% от вес пропп нт . к пок зыв ет 3 рубежный опыт применения стекловолокон, вынос пропп нт в этом случ е не превыш ет $0,2 \%$ от 3 к чив емого объем . ля применения отечественного стекловолокн требуется проведение его л бор торных исследов ний и промысловых испыт ний.

ля условий п дной ибири, в ч стности для скв жин ов ненковского месторождения, необходимо применять жидкостную систему, обеспечив ющую миним льные 3 тр ты н проведение ремонтных р бот и увеличив ющую продуктивность скв жины после обр ботки пл ст (н пример, жидкостную систему HIGHSHEAR), т кже специ льные доб вки, улучш ющие деструкцию (р сп д) сшитых полимеров в трещине (н пример, смесь доб вок под н зв нием CleanFLOW). к пок зыв ет з рубежный опыт, применение т ких доб вок позволяет увеличив ть прониц емость пропп нтной н бивки от 40 до $90 \%$.

ля освоения р сконсервируемой скв жины после з вершения и восст новления г зодин мической связи пл ст со скв жиной лучше всего использов ть колтюбинговую уст новку в сочет нии с мощной зотной уст новкой для осушки приз бойной зоны. кое сочет ние будет способствов ть очень быстрому выходу скв жин н проектные режимы. ызов приток из пл ст в этом случ е осуществляется с применением пенной зотиров нной системы с доб влением ингибитор глин и понизителя трения.

рименение двухфр кционной технологии при р сконсерв ции скв жин позволяет обеспечить:

- крепление трещины р зрыв высокопрочным пропп нтом в прискв жинной зоне, где н пряжение сж тия н иболее высокое;

- созд ние н ибольшей проводимости трещины р зрыв в приз бойной зоне, где скорость фильтр ции флюид м ксим льн я;

- предотвр щение вынос пропп нт в скв жину после з вершения , обеспечив емое специ льным подбором р зницы в $р$ змер х зерен основного и з к нчив ющего р склинив ние трещины р зрыв пропп нтов, при котором зерн меньшего р змер 3 держив ются н гр нице между этими пропп нт ми;

- блокиров ние мелкозернистым пропп нтом оконч ния трещины р зрыв и естественных микротрещин, ответвляющихся от основной трещины, что сниж ет потери жидкости р зрыв и улучш ет проводимость трещины р зрыв .

ким обр зом, для р сконсерв ции скв жин, длительное время н ходящихся в консерв ции или в бездействии, н иболее оптим льным является технология двухфр кционного с использов нием колтюбинговых уст новок.

\footnotetext{
1. устышев собенности $\mathrm{p}$ сконсерв ции скв жин, длительное время н ходяшихся в консерв ции или в бездействующем фонде // роблемы сбор , подготовки и тр нспорт нефти и нефтепродуктов. - 2009. - № 3. - . 19-23.

2. рименение гидрор зрыв пл ст для интенсифик ции приток н г зоконденс тных скв жин х мбургского месторождения и перспективы применения метод в процессе д льнейшего освоения з лежей / . . инченко,

3. лещенко . . и др. идрор зрыв г зоконденс тных объектов н месторождениях север п дной ибири / . . лещенко, . . рылов, . . охошко. - юмень: ектор ук, 2007. -211 с.

4. учков . . нтенсифик ция р боты скв жин. - . жевск: зд-во «егулярн я и х отическ я дин мик », нститут компьютерных исследов ний, 2007. -612 с.

5. кономидис . и др. нифициров нный диз йн гидрор зрыв. ведение мостов между теорией и пр ктикой / . кономидис, . лйни, . лько/ ер. . глов . - зд-во « pс ресс лвин», шт. ех с, .: етро льянс ервисис омп нии им тед, 2004.-194 с.

6. оследние достижения в технологии гидр влического р зрыв пл ст / од ред. жон . идли и др. - здво « рс ресс лвин», шт. ех с. - 6 том х. -2006.

7. устышев . ., устышев . . сконсерв ция скв жин н месторождениях п дной ибири / тв. ред. д. т. н., профессор . . . устышев. - юмень: ектор ук, 2013. - 192 с.

ведения об вторе

устышев енис лекс ндрович, к. н учный сотрудник мень, тел. 8(3452)286697

Information about the author

Kustyshev D. A., Candidate of Science in Engineering, senior scientific worker of $L C$ «TyumenNIIgiprogas», phone $8(3452) 286697$
} 